\title{
INTRODUCING NATURE-SAVING TECHNOLOGIES AS AN ENVIRONMENTAL IMPERATIVE IN THE DEVELOPMENT OF REGIONS
}

\author{
Ljudmila N. Medvedeva \\ All-Russian Research Institute of Irrigated Agriculture, Volgograd, Russian Federation; \\ Volzhsky Polytechnical Institute, Branch of Volgograd State Technical University, Volzhsky, Russian Federation
}

\section{Maria V. Frolova}

All-Russian Research Institute of Irrigated Agriculture, Volgograd, Russian Federation

\section{Maria V. Moskovets}

All-Russian Research Institute of Irrigated Agriculture, Volgograd, Russian Federation

\author{
Artem V. Medvedev \\ All-Russian Research Institute of Irrigated Agriculture, Volgograd, Russian Federation
}

\begin{abstract}
The article deals with the conservation and restoration of water resources, which is one of the basic factors of regional development. O.V. Inshakov paid attention to this factor highlighting natural resources (land, water, minerals, forests and others) with a certain set of indicators of quantity, structure and quality in the structural and logical model of the development of Volgograd region - 2030. One of the key directions of the civilization development in the $20^{\text {th }}$ century was the search and practical application of a new class of technological and technical solutions in the field of water conservation with the ecological imperative "preserve nature for future generations". This implies the gradual elimination of their practices of economic activity processes that can lead to irreversible consequences in the ecosystem of the planet. In this context, the issues raised in the article on the study and preservation of natural water quality in the South of Russia are veryjustified and relevant. As a result of the anthropogenic impact (pollution by industrial, agricultural $\oplus$ and municipal effluents), nitrogen, phosphorus, chlorine-containing substances causing fatal mutations and the process of "blooming" of water bodies are concentrated in excess in natural water. Many countries face the problem of "blooming" $\stackrel{0}{*}$ of water bodies as a result of intensive growth of blue-green algae. The importance of solving this problem is explained by the fact that the toxins entering water from the biological activity of blue-green algae are very dangerous for human health and other organisms. Scientific literature provides examples of human diseases from using water with a significant amount of cyanobacteria blooms. When "blooming" biomass of blue-green algae accumulates in the coastal part and causes technical difficulties in supplying water to the water supply network, the formation of overseas zones and the death of hydrobionts. Existing methods of combating "blooming" have a number of significant drawbacks, for example, mechanical methods require high financial costs, and chemical ones are environmentally unsafe. The article presents the results of the scientific research of the All-Russian Research Institute of Irrigated Agriculture, Volgograd (Volgograd) on using biotechnology for natural water purification. The experiment on introducing Chlorella vulgaris IGF no. C-111 microalgae into the bays of the Volgograd reservoir was carried out on the basis of preliminary compilation of the $\Sigma$ hydrological characteristics of the reservoir bays, determination of hydrobiological and hydrochemical qualities of water. The aim of the work was to substantiate the technology of introducing Chlorella vulgaris IFR no. C-111 strain into the bays of the Volgograd reservoir and to obtain data confirming the scientific hypothesis - the expediency of using Chlorella vulgaris IFR no. C-111 strain to improve the hydrobiological and hydrochemical composition of natural water. Key words: water resources, reservoir, eutrophication, methods of water quality assessment, water treatment technology, ecology, blue-green algae, Chlorella vulgaris strain, algolization, hydrochemical and hydrobiological indicators, regional economic effect.
\end{abstract}

Citation. Medvedeva L.N., Frolova M.V., Moskovets M.V., Medvedev A.V. Introducing Nature-Saving Technologies as an Environmental Imperative in the Development of Regions. Journal of Volgograd State University. Economics, 2019, vol. 21, no. 4, pp. 126-140. (in Russian). DOI: https://doi.org/10.15688/ek.jvolsu.2019.4.13 
Внедрение природосберегающих технологий - экологический императив в развитии регионов

\title{
ВНЕДРЕНИЕ ПРИРОДОСБЕРЕГАЮЩИХ ТЕХНОЛОГИЙ - ЭКОЛОГИЧЕСКИЙ ИМПЕРАТИВ В РАЗВИТИИ РЕГИОНОВ
}

\author{
Людмила Николаевна Медведева \\ Всероссийский научно-исследовательский институт орошаемого земледелия, \\ г. Волгоград, Российская Федерация; \\ Волжский политехнический институт (филиал) ВолгГТУ, г. Волжский, Российская Федерация
}

\section{Мария Викторовна Фролова}

Всероссийский научно-исследовательский институт орошаемого земледелия, г. Волгоград, Российская Федерация

\section{Мария Васильевна Московец}

Всероссийский научно-исследовательский институт орошаемого земледелия, г. Волгоград, Российская Федерация

\section{Артем Владимирович Медведев}

Всероссийский научно-исследовательский институт орошаемого земледелия, г. Волгоград, Российская Федерация

Аннотация. В статье рассматриваются вопросы сохранения и восстановления водных ресурсов, являющихся одним из базисных факторов развития регионов. На это обращал внимание О.В. Иншаков, выделяя в структурно-логической модели развития Волгоградской области - 2030 природные ресурсы (земельных, водных, ископаемых, лесных и иных) с определенным набором показателей количества, структуры и качества. Одним из ключевых направлений развития цивилизации в XX в. стал поиск и применение на практике нового класса технологических и технических решений в области сохранения водных ресурсов с экологическим императивом «сохраним природу для будущих поколений». Это подразумевает постепенное исключение из практики хозяйственной деятельности процессов, которые могут привести к необратимым последствиям в экосистеме планеты. В этом контексте вопросы, поднимаемые в статье по изучению и сохранению качества природной воды на Юге России, являются весьма оправданными и актуальными. В результате антропогенного воздействия (загрязнения промышленными, сельскохозяйственными и коммунальными стоками) в природной воде в избытке концентрируется азот, фосфор, хлорсодержащие вещества, вызывающие смертельные мутации и процесс «цветения» водоемов. С последней из указанных проблем в результате интенсивного роста синезеленых водорослей сталкиваются многие страны. Важность решения этой задачи объясняется тем, что поступающие в воду токсины от биологической деятельности синезеленых водорослей весьма небезопасны для здоровья человека, других организмов. В научной литературе приводятся примеры заболеваний человека от использования воды со значительным количеством цианобактериальных блюмов. При «цветении» биомасса синезеленых водорослей скапливается в прибрежной части и вызывает технические трудности при подаче воды в водопроводные сети, образование заморных зон и гибель гидробионтов. Существующие методы борьбы с «цветением» имеют ряд существенных недостатков: так, механические требуют высоких финансовых затрат, а химические - экологически небезопасны. В статье представлены результаты научных исследований ФГБНУ ВНИИОЗ (г. Волгоград) по использованию биотехнологий для очистки природной воды. Эксперимент по вселению микроводоросли Chlorella vulgaris ИФР № C-111 в заливы Волгоградского водохранилища проводился на основе предварительного составления гидрологической характеристики заливов водохранилища, определения гидробиологических и гидрохимических качеств воды. Цель работы заключалась в обосновании технологии вселения штамма Chlorella vulgaris ИФР № C-111 в заливы Волгоградского водохранилища и получении данных, подтверждающих научную гипотезу-целесообразности применения штамма Chlorella vulgaris ИФР № C-111 для улучшения гидробиологического и гидрохимического состава природной воды.

Ключевые слова: водные ресурсы, водохранилище, эвтрофирование, методы оценки качества воды, технология очистки воды, экология, синезеленые водоросли, штамм Chlorella vulgaris, альголизация, гидрохимические и гидробиологические показатели, региональный экономический эффект. 
Цитирование. Медведева Л. Н., Фролова М. В., Московец М. В., Медведев А. В. Внедрение природосберегающих технологий - экологический императив в развитии регионов // Вестник Волгоградского государственного университета. Экономика. - 2019. - Т. 21, № 4. - С. 126-140. - DOI: https://doi.org/10.15688/ ek.jvolsu.2019.4.13

\section{Введение}

Актуальность создания экологически приемлемых технологий восстановления водных объектов обосновывается возрастающей антропогенной нагрузкой на природные экосистемы. Стратегически важной эта тема стала в рамках принятых документов: «Стратегии адаптации и противодействия Глобальному изменению климата» (Paris Climate Agreement, 2015 год), «Программы устойчивого развития мира до 2030 года» (Sustainable Development Goals 2030) [Final Draft of Climate..., 2015; United Nations Official..., 2018].Согласно прогнозам ООН к 2050 г. население Земли должно достигнуть - 9,1 млрд чел. (в 2000 г. было 6,8 млрд чел.), потребление водных ресурсов - увеличиться до 70 \%. Российская Федерация - одна из немногих стран мира, которая имеет уникальный водно-ресурсный потенциал: 30 тыс. водохранилищ с объемом свыше 800 км $^{3} ; 2,7$ млн озер с суммарной площадью водной поверхности 409 тыс. км ${ }^{2}$ (98 \% озер небольшие - менее 1 км², мелководные - глубина 1-1,5 м; 3000 км каналов межбассейнового и внутрибассейнового перераспределительного стока с объемом 17 км$^{3}$ в год [Водная стратегия..., 2009]. Сложившийся уровень антропогенного воздействия на водные объекты в европейской части страны вызывает значительные опасения и требует не только мониторинга, но и поиска новых научных подходов к обеспечению рационального природопользования [О Стратегии экологической безопасности..., 2017]. Достаточно сложная экологическая обстановка, сложившаяся в бассейнах рек Волги и Дона (вода для питьевого и хозяйственно-бытового водоснабжения считается здесь условно пригодной), требует исследований и решений, направленных на предотвращение поступления в воду неочищенных стоков и обеспечение необходимого качества природной воды [Медведева и др., 2017; Проблема развития аквакультуры..., 2016]. Источники поступления загрязняющих веществ в водоемы подразделяются на организованные и диффузные, связанные, главным образом, с усевающемся сельскохозяйственным и промышленным производством. Больше всего загрязняющих веществ поступает с коммунальными стоками от городов и сельских поселений. Согласно исследованиям выход с продуктами обмена человека азота составляет - 15 г/сутки, фосфора - 1,4 г/сутки. Хозяйственная деятельность предприятий и организаций добавляет ежесуточно от 5 до10 г азота и до 1,4 г фосфора [Шилькрот, 2017]. Промышленные стоки не дают такого экологического значения в эвтрофировании водоемов, как сбрасываемые коммунальные стоки городов и сельскохозяйственных поселений. Единого механизма, способного эффективно защищать водоемы как от экзо-, так и от эндогенного загрязнения, пока не найдено. Скорее всего, решение этой проблемы будет одной из главных научных задач XXI века. Если в прошлом веке очистка водоемов обеспечивалась за счет механических и химических методов, то сегодня на повестке дня стоит цель: обеспечить очистку загрязненных водоемов природосберегающими технологиями и механизмами, восстанавливающими сохранение биоценозов [О Стратегии экологической безопасности..., 2017]. Разнообразные группы растений, обитающие в водоемах, являются их неотъемлемой частью, обеспечивающей нормальное функционирование и устойчивость водных экосистем (см. рис. 1).

Одни группы водных растений продуцируют кислород, создавая благоприятные физико-химические условия для обитания остальных гидробионтов; другие, например, микроскопические водоросли, являются начальным звеном в пищевых цепочках водоемов; макрофиты, в свою очередь, формируют среду обитания и служат источником питания для многих животных и рыб, обитающих в водоемах; растения, произрастающие по берегам, укрепляют береговую линию, препятствуют абразии и взмучиванию донных отложений и, как следствие, обеспечивают снижение мутности воды и большее поступление солнечного цвета [Мелихов, 2016]. 


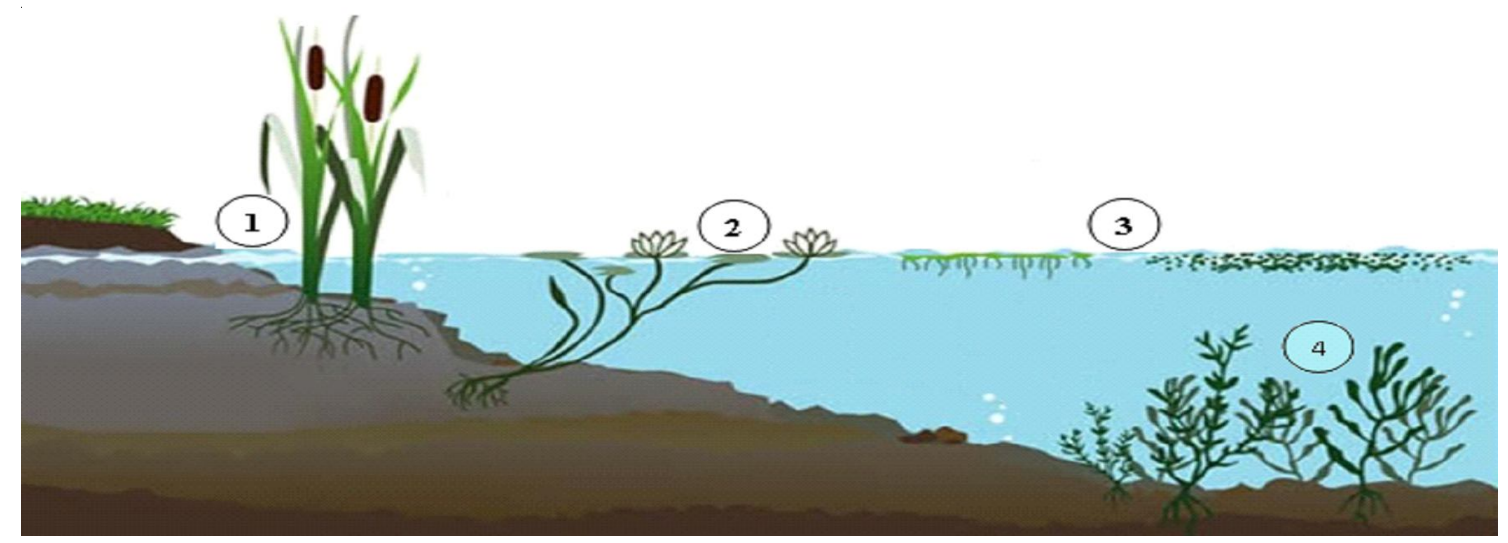

Рис. 1. Основные экологические группы растений, обеспечивающих устойчивость водных экосистем:

1 - полупогружные (гидрофиты) растения; 2 - плавающие (аэрогидатофиты) растения; 3 - водоросли, плавающие в толще воды; 4 - погруженные (гидатофиты) под воду растения

Целью очистки водоемов с помощью различных технологий является достижение баланса интересов между разными видами живых организмов, растений и человека. Методы очистки и оздоровления водоемов подразделяются на физические, механические, химические и биологические. В системе мероприятий по реабилитации водных объектов хорошо зарекомендовали себя физические методы, начиная от простого механического удаления и искусственного затенения акватории и заканчивая инновациями на основе применения зеленых технологий. Средства механического удаления (косы, грабли, электромеханические устройства, работающие автономно или под управлением человека) предназначены для борьбы с чрезмерным развитием высших вод- ных растений [Мелихов, 2016; Медведев и др., 2019]. На рис. 2 представлены механические и электронные средства для очистки водоемов.

Ультразвуковые приборы успешно применяются в США, Канаде, Японии и Нидерландах. Существенный недостаток: ультразвуковые излучатели воздействуют не только на синезеленые водоросли, погибнуть могут другие микроорганизмы биоты, например, хлорелла. За рубежом широко используются для предупреждения «цветения» водоемов конструкции «constructed wetlands». Это «биоплато», которые размещаются на водной глади и не пропускают в водоем солнечные лучи, препятствуют бурному «цветению» синезеленых водорослей. Химический метод очистки сводится ко внесению в водоем медного купоро-
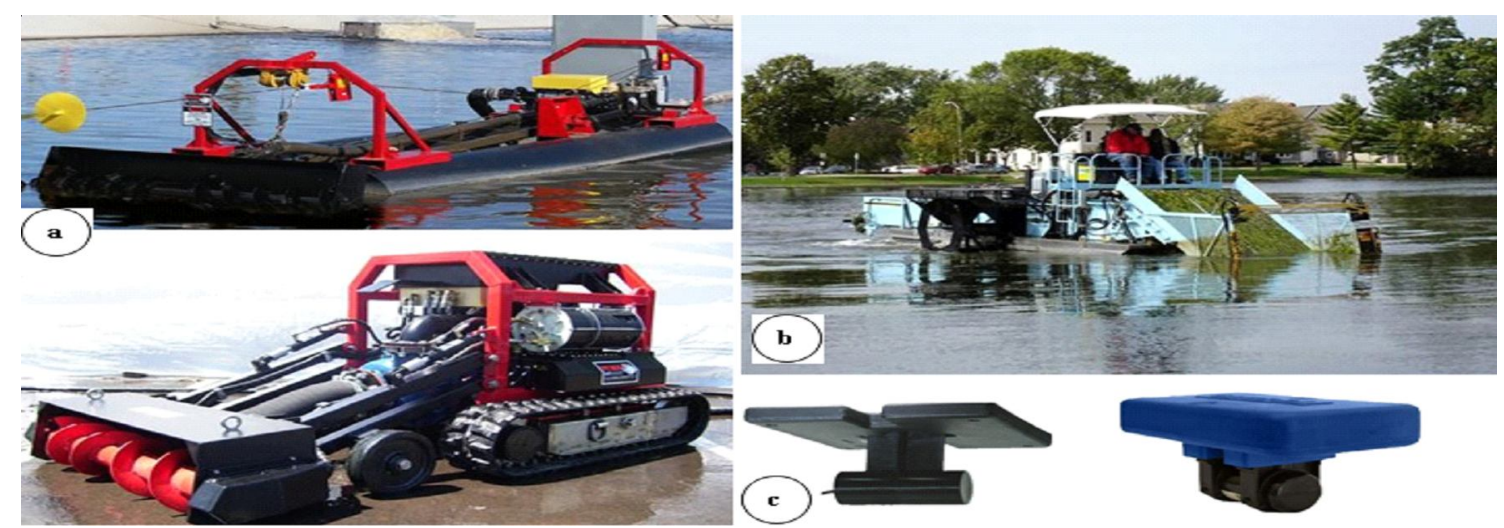

Рис. 2. Механические и ультразвуковые средства очистки водоемов:

$a$ - автоматизированные малогабаритные земснаряды со шнековыми грунторыхлителями: надводный PHE-40HР и подводный ROV-6 PitDog (www.lwtpithog.com);

$b$ - комбайн для сбора водных растений AquariusSystems 320 серии (www.aquarius-systems.com); $c$ - ультразвуковые излучатели Sonic Solutions (США) и LG Sonic (Нидерланды) 
са, газообразного хлора, хлорной извести, а для малых водоемов - соединений серебра. Несмотря на временный положительный эффект, данных, подтверждающих безопасность человека и других живых организмов при воздействии химических соединений, в публикациях практически не наблюдается. Известно, что при дозе хлора 0,1 мг/л в присутствии большого количества планктона развитие синезеленых водорослей не угнетается, а при дозе - 1,0 мг/л наоборот - только увеличивается [Мелихов, 2016; Медведев и др., 2019].

В число биологических методов входят биоаугментация и альголизация водоемов. В качестве примера биоаугментации можно привести внесение в водоем российского препарата микрозим Понд Трит - смесь от 6 до 12 видов аэробных мезофильных микроорганизмов, для которых основным источником жизнедеятельности являются свободные органические вещества. Растворенные в воде и донных отложениях. Технология альголизаичи стала применяться с конца XX в., основана на внесении в водоем зеленой водоросли Chlorella vulgaris, что позволяет снизить количество синезеленых водорослей в биоценозе, убрать эффект «цветения» водоема. В основе данной технологии лежит аксиома, что между синезелеными и зелеными водорослями в фитопланктонном сообществе складываются антагонистические отношения [Green Technologies..., 2017; Мониторинг экологического состояния..., 2017].

Алгоритм биологической реабилитации водоемов заключается в уничтожении зелеными водорослями синезеленых, в минимизации загрязняющих веществ, предотвращении «цветения» водоемов. Внесенный в водоем штамм Chlorella vulgaris ИФР № С-111 проявляет хорошо выраженные антагонистические свойства к альгофлоре, бактериям, грибам, дрожжам и инфузориям. В течение суток наступает лизис грибов, дрожжей, синезеленых водорослей, которые, погибая, осаждаются на дно. Метод альголизации требует дальнейших исследований, поскольку достаточно трудно просчитать период, за который произойдет оздоровление водоема. Также известно, что альголизация (без предварительного исследования состояния водоема) может не только не улучшить экологическую обста- новку в экобиоценозе, но и спровоцировать рост «нежелательных» для человека организмов. Несмотря на естественность биологических методов оздоровления водоемов, сторонников неэффективности альголизации немало, и аргументация их выводов основывается как раз на ошибках, допущенных при применении данной технологии. Цель исследования и состояла в том, чтобы создать доказательную базу правомерности применения штамма Chlorella vulgaris ИФР № С-111 для оздоровления экосистем Волгоградского водохранилища [Мониторинг экологического состояния..., 2017; Фролова и др., 2018].

Волгоградское водохранилище, расположенное на Юге России, относится к группе водоемов, испытывающих на себе высокую антропогенную нагрузку. Протяженность водохранилища - 546 км, площадь водного зер-

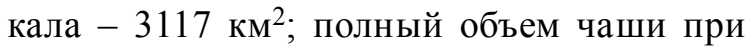
НПУ $-31,45$ км $^{3}$, средняя глубина $-10,0$ м, максимальная - 41,0 метр. Водохранилище относится к русловому, приточно-аккумулирующему типу с достаточно проточной глубоководной частью. Специфика гидрологоморфологических, климатических и биологических характеристик позволяет подразделить водохранилище на три участка: верхний, средний и нижний (приплотинный) [Медведева и др., 2017].

Водохранилище имеет многоцелевое назначение, и эффект «цветения» воды отрицательно сказывается на всех аспектах жизни людей, проживающих в данном регионе. Основная биомасса синезеленых водорослей скапливается в прибрежной части водохранилища, и «цветение» вызывает технические трудности при заборе воды для питьевых и хозяйственных нужд. Разлагающиеся водоросли снижают содержание кислорода и вызывают образование заморных зон и гибель гидробионтов. Теплая вода и наличие солнечного света способствуют бурному росту синезеленых водорослей из родов Anabaena, Aphanizomenon, Microcystis, Oscillatoria [Проблемы экологического состояния..., 2018]. «Цветение» водорослей в конце летнего периода значительно ухудшает гидрохимические, санитарно-гигиенические и рыбохозяйственные показатели воды. Ученые ФГБНУ ВНИИОЗ (г. Волгоград) более 15 лет 
изучают влияние штамма микроводоросли Chlorella vulgaris ИФР № C-111 на водные объекты. Волгоградское водохранилище входит в число научных объектов, где проводятся исследования по влиянию штамма Chlorella vulgaris ИФР № С-111 на водные организмы по предотвращению эффекта «цветения» волжской воды [Проблемы экологического состояния..., 2018].

\section{Материалы и методы}

При проведении исследования изучалась региональная эффективность от вселения штамма Chlorella vulgaris ИФР № С-111 в заливы Волгоградского водохранилища. Методы системного и мониторингового анализа позволили обосновать рабочую гипотезу проведенного исследования. Наблюдения и сбор гидрологического, гидрохимического и гидробиологического материала проводились на шести «станциях» Волгоградского водохранилища: Ерзовская, Дубовская, Балыклейская, Еруслановская, Яблоневая, Красные отмели в течение 2017 года. Для определения размеров и площади заливов применялись масштабированные данные спутниковой фотофиксации, полученные с помощью интерактивной web-программы Google Earth. Исследование состояния фитопланктона проводилось батометром Молчанова, скляночным кислородным методом Г.Г. Винберга. Для оценки качества воды использовалась шкала, представленная в «Рекомендациях Минприроды по выявлению зон чрезвычайной экологической ситуации и зон экологического бедствия»; для характеристики загрязнения водоема по бентосу применялся индекс сапробности; для оценки качества поверхностных вод использовался индекс Гуднайта - Уитли.

Для оценки влияния штамма Chlorella vulgaris ИФР № C-111 на параметры экосистемы водохранилища в районах ее вселения использовался индекс функции «желательности». Метод исчисления функции «желательности» применяется в прикладных экологических исследованиях для интегрирования многомерной информации.

Индекс «желательности» (далее - D) представляет собой способ перевода нату- ральных значений показателей в единую безразмерную числовую шкалу с границами от 0 до 1. Максимальный показатель функции «желательности» соответствует - 1 , минимально «желательное число»- 0 . Перевод различных параметров экосистемы в единую цифровую шкалу функции «желательности» производился по формуле:

$$
D=\sqrt[n]{d_{1} \cdot d_{2} \cdot d_{3} \ldots d},
$$

где $d_{1}, d_{2}, \ldots d_{i}$ - частные функции «желательности» $i$-го показателя; $n$ - число показателей.

В исследовании в качестве индикаторных показателей, характеризующих состояние контрольного и экспериментальных участков экосистемы, были использованы: 1 - концентрация растворенного кислорода в воде, 2 прозрачность воды, 3 - биомасса зеленых водорослей, 4 - биомасса зоопланктона, 5 биомасса синезеленых водорослей.

С позиции экологических требований «желательными» будут являться первые четыре показателя, «нежелательным» - последний. В ходе исследования было отобрано по 100 проб каждой экологической группы гидробионтов: численность бактерий учитывалась методом ультрафильтрации; биомасса микроорганизмов рассчитывалась исходя из общего количества бактерий и среднего объема бактериальных клеток; пробы зоопланктона производились с помощью количественной сети Джеди путем тотального облова столба воды от дна до поверхности.

В ходе исследования было определено 33 таксономических группы организмов с показателями численности (тыс. экз./м²) и биомассы $\left(\mathrm{мг} / \mathrm{M}^{2}\right)$. Отнесение проб воды к тому или иному классу производилось по таблице 1.

\section{Результаты и обсуждение}

В разработанной О.В. Иншаковым структурно-логической модели «Стратегии социально-экономического развития Волгоградской области - 2030» одним из составляющих структурных элементов являются природные ресурсы (земельных, водных, ископаемых, лесных и иных), которые оцениваются в показателях количества, структуры и качества. 


\section{Классификация качества воды водоемов по гидробиологическим показателям}

\begin{tabular}{|c|c|c|c|}
\hline \multirow{2}{*}{$\begin{array}{c}\text { Класс } \\
\text { качества } \\
\text { воды }\end{array}$} & \multirow{2}{*}{$\begin{array}{c}\text { Степень } \\
\text { загрязненности } \\
\text { воды }\end{array}$} & \multicolumn{2}{|c|}{ Гидробиологические показатели по зообентосу } \\
\hline & & $\begin{array}{l}\text { Отношение общей численно- } \\
\text { сти олигохет к общей числен- } \\
\text { ности донных организмов, \% }\end{array}$ & $\begin{array}{l}\text { Биотический } \\
\text { индекс по Ву- } \\
\text { дивиссу, баллы }\end{array}$ \\
\hline I & Очень чистая & $1-20$ & 10 \\
\hline II & Чистая & $21-35$ & $7-9$ \\
\hline III & $\begin{array}{l}\text { Умеренно } \\
\text { загрязненная }\end{array}$ & $36-50$ & $5-6$ \\
\hline IV & Загрязненная & $51-65$ & 4 \\
\hline $\mathrm{V}$ & Грязная & $66-85$ & $2-3$ \\
\hline VI & Очень грязная & $\begin{array}{c}\text { 86-100 или макрозообентос } \\
\text { отсутствует }\end{array}$ & 1 \\
\hline
\end{tabular}

Примечание. Составлено авторами.

Автор приводит сведения, что Волгоградская область по доле населения, обеспеченного питьевой водой, отвечающей требованиям безопасности, занимает 37-е место [Иншаков, 2017].

Критическое осмысление и творческий подход к развитию региона нацеливает авторов на поиск резервов и качественных точек роста. Кластерный подход в развитии Волгоградского региона - один из методов, который на основе разумных выборок позволяет построить структурно-логические модели использования природных ресурсов, в частности водных [Медведев и др., 2019].

При обследовании акватории Волгоградского водохранилища была построена матрица движущих факторов состояния природного фитопланктона, позволяющая определить участки водоема, наиболее подверженные антропогенному воздействию (табл. 2) [Мониторинг экологического состояния..., 2017].

Для сохранения, поиска оптимальных технологий очистки природных вод учеными
ФГБНУ ВНИИОЗ (г. Волгоград) проводятся исследования в акватории Волгоградского и Цимлянского водохранилищ. Для оценки влияния штамма Chlorella vulgaris ИФР № C-111 на параметры экосистемы водохранилища были выбраны заливы Волгоградского водохранилища и установлены шесть «станций» наблюдений: Ерзовская, Дубовская, Балыклейская, Еруслановская, Красные отмели, Яблоневая (см. рис. 3).

Исследуемые заливы Волгоградского водохранилища имеют существенные различия по размерам и площади водного зеркала (см. табл. 3).

Максимальными размерами обладают экспериментальные заливы (1-4), куда производилось вселение штамма Chlorella vulgaris ИФР № С-111. В табл. 4 приведены данные мониторинга исследуемых заливов по гидрофизическим параметрам в летнюю межень.

В табл. 5 приведены данные вселения суспензии штамма Chlorella vulgaris ИФР № C-111 в экспериментальные заливы в 2017 году.

Таблица 2

Матрица движущих факторов вариации сообществ фитопланктона Волгоградского водохранилища

\begin{tabular}{|l|l|l|}
\hline & \multicolumn{1}{|c|}{$\begin{array}{c}\text { Качество воды: } \\
\text { физические факторы }\end{array}$} & \multicolumn{1}{|c|}{$\begin{array}{c}\text { Качество воды: } \\
\text { химические факторы }\end{array}$} \\
\hline $\begin{array}{l}\text { Менее подвержены } \\
\text { влиянию человеческой } \\
\text { деятельности }\end{array}$ & $\begin{array}{l}\text { Температура воды (WT), } \\
\text { Проводимость (Cond) }\end{array}$ & $\begin{array}{l}\text { Общий фосфор (TP), } \\
\text { аммиачный азот (NH } 4 \text {-N), } \\
\text { химическая потребность в } \\
\text { кислороде (COD) }\end{array}$ \\
\hline $\begin{array}{l}\text { Более подвержены } \\
\text { влиянию человеческой } \\
\text { деятельности }\end{array}$ & $\begin{array}{l}\text { Температура воды (WT), } \\
\text { Проводимость (Cond) }\end{array}$ & $\begin{array}{l}\text { Растворенный кислород (DO), } \\
\text { химическая потребность в } \\
\text { кислороде (COD) }\end{array}$ \\
\hline
\end{tabular}

Примечание. Составлено авторами. 
Внедрение природосберегающих технологий - экологический императив в развитии регионов

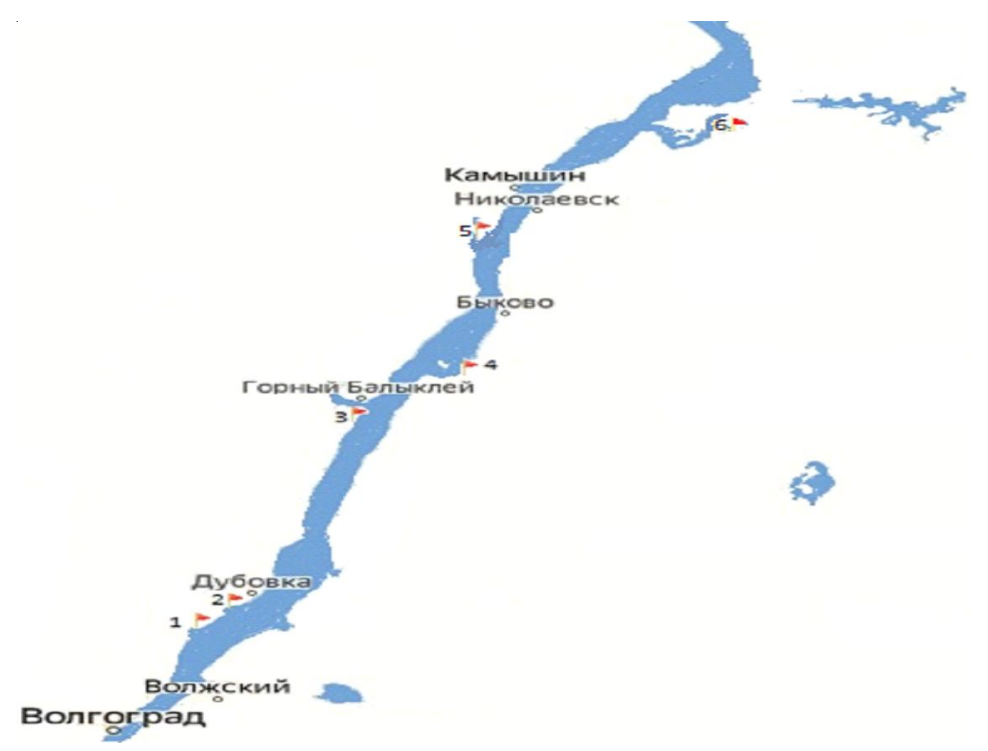

Рис. 3. Карта-схема размещения станций исследования на Волгоградском водохранилище:

1 - Ерзовская; 2 - Дубовская; 3 - Балыклейская; 4 - Еруслановская; 5 - Красные отмели; 6 - Яблоневая

Общая характеристика исследованных заливов Волгоградского водохранилища

Таблийа 3

\begin{tabular}{|l|l|c|c|c|c|c|}
\hline Заливы & Расположение & $\begin{array}{c}\text { Площадь, } \\
\text { га }\end{array}$ & $\begin{array}{c}\text { Ширина } \\
\text { в устье, м }\end{array}$ & $\begin{array}{c}\text { Ширина в } \\
\text { средней } \\
\text { части, м }\end{array}$ & $\begin{array}{c}\text { Ширина в } \\
\text { верхней } \\
\text { части, м }\end{array}$ & Длина, км \\
\hline \multicolumn{7}{|c|}{ Экспериментальн ые заливы для проведения альголизации } \\
\hline 1. Ерзовский & Правобережный & 87 & 750 & 250 & 110 & 3,2 \\
\hline 2. Дубовский & Правобережный & 34 & 240 & 200 & 120 & 2,3 \\
\hline 3. Балыклейский & Правобережный & 1550 & 1800 & 1100 & 400 & 13,0 \\
\hline 4. Еруслановский & Левобережный & 6660 & 1700 & 1500 & 1500 & 31,0 \\
\hline \multicolumn{7}{|c|}{ Контрольные заливы для проведения альголизации } \\
\hline 5. Красные отмели \\
\hline П. Яблоневый & Правобережный & 1780 & 1050 & 930 & 370 & 17,0 \\
\hline
\end{tabular}

Примечание. Составлено авторами.

Таблица 4

Гидрофизические параметры заливов Волгоградского водохранилища в летнюю межень 2017 года

\begin{tabular}{|c|c|c|c|c|}
\hline Заливы & Месяц & $\mathrm{t}^{\mathrm{O}} \mathrm{C}$ & $\begin{array}{c}\text { Прозрачность, } \\
\text { м }\end{array}$ & $\begin{array}{c}\text { Растворенный } \\
\text { кислород, } \mathrm{MгO}_{2} / \text { дм }^{3}\end{array}$ \\
\hline \multirow[t]{4}{*}{ Ерзовский } & июнь & 20.9 & 0.5 & 7.8 \\
\hline & июль & 23.2 & 2.3 & 10.2 \\
\hline & август & 26.3 & 0.5 & 16.5 \\
\hline & сентябрь & 19.0 & 0.5 & 12.1 \\
\hline \multirow[t]{4}{*}{ Дубовский } & июнь & 20.9 & 2.0 & 11.9 \\
\hline & июль & 22.5 & 2.3 & 11.4 \\
\hline & август & 25.3 & 0.7 & 10.3 \\
\hline & сентябрь & 18.6 & 2.0 & 10.5 \\
\hline \multirow[t]{4}{*}{ Балыклейский } & июНь & 21.6 & 0.7 & 8.9 \\
\hline & июль & 24.3 & 0.7 & 8.5 \\
\hline & август & 27.5 & 0.7 & 10.5 \\
\hline & сентябрь & 18.0 & 0.7 & 13.1 \\
\hline \multirow[t]{4}{*}{ Еруслановский } & июнь & 24.4 & 0.3 & 14.8 \\
\hline & июль & 22.9 & 1.0 & 8.5 \\
\hline & август & 23.8 & 2.0 & 10.6 \\
\hline & сентябрь & 16.3 & 1.0 & 12.4 \\
\hline
\end{tabular}


Окончание таблицьы 4

\begin{tabular}{|c|c|c|c|c|}
\hline Заливы & Месяц & $\mathrm{t}^{\circ} \mathrm{C}$ & $\begin{array}{c}\text { Прозрачность, } \\
\text { м }\end{array}$ & $\begin{array}{c}\text { Растворенный } \\
\text { кислород, } \text { мгО }_{2} / \text { дм }^{3}\end{array}$ \\
\hline \multirow{4}{*}{ Красные отмели } & июнь & 22.4 & 0.8 & 9.1 \\
\cline { 2 - 5 } & июль & 23.5 & 0.7 & 7.7 \\
\cline { 2 - 5 } & август & 19.1 & 0.8 & 7.6 \\
\cline { 2 - 5 } & сентябрь & 17.9 & 0.6 & 7.0 \\
\hline \multirow{4}{*}{ Яблоневый } & июнь & 23.5 & 0.7 & 9.6 \\
\cline { 2 - 5 } & июль & 24.4 & 0.6 & 7.1 \\
\cline { 2 - 5 } & август & 24.8 & 1.2 & 8.3 \\
\cline { 2 - 5 } & сентябрь & 17.5 & 1.0 & \\
\hline
\end{tabular}

Примечание. Составлено авторами.

Объемы вселения суспензии штамма Chlorella vulgaris ИФР № C-111 в заливы Волгоградского водохранилища (2017 год), литры

\begin{tabular}{|l|c|c|c|c|c|c|c|}
\hline $\begin{array}{c}\text { Наименование } \\
\text { заливов }\end{array}$ & Март & Апрель & Май & Июнь & Июль & Август & Сентябрь \\
\hline \multicolumn{8}{|c|}{ Экспериментальные заливы } \\
\hline Ерзовский & 20 & 20 & 40 & 60 & 60 & 60 & - \\
\hline Дубовский & 20 & 20 & 20 & 40 & 40 & 20 & - \\
\hline Балыклейский & 40 & 100 & 60 & 100 & 60 & 60 & 40 \\
\hline Еруслановский & 100 & 100 & 100 & 100 & 100 & 60 & 40 \\
\hline \multicolumn{7}{|c|}{ Контрольные заливы } \\
\hline Красные отмели & - & - & - & - & - & - & - \\
\hline Яблоневый & - & - & - & - & - & - & - \\
\hline
\end{tabular}

Примечание. Составлено авторами.

Наблюдения за гидрофизическими показателями заливов показало, что изменение прозрачности по времени было связано с уровнем развития фитопланктона, наличием взвешенных веществ, количество которых регулировалось интенсивностью взмучивания при ветровом перемешивании воды. Содержание растворенного кислорода не опускалось ниже рыбохозяйственной нормы, было на уровне: 7,5-19,4 мг О $2 /$ дм³ $^{3}$. Максимальные показатели кислорода - 12,4-19,4 мг О $\mathrm{O}_{2}$ дм $^{3}$ - были зарегистрированы в экспериментальных заливах водохранилища.

Сравнение состояния экспериментальных и контрольных заливов показало, что вселение хлореллы, в большей мере, повлияло на показатели состава и свойств воды заливов левобережья. В экспериментальных заливах по сравнению с контрольными произошло снижение концентрации биогенных элементов; уменьшение соединений азота и фосфора в $2,3-3,5$ раза, суммы биогенов - в 1,3 раза.

Среднесезонная численность бактериопланктона нижней зоны Волгоградского водохранилища составила 2,4 млн/мл, биомасса -
1,8 г/м $\mathbf{m}^{3}$. Общая численность бактериопланктона в экспериментальных заливах была более высокой по сравнению с контрольными и колебалась в пределах от 2,6 до 3,8 млн кл/мл. В контрольных заливах и в водохранилище данные по бактериопланктону различались незначительно и в среднем составили 2,4 млн кл/мл,

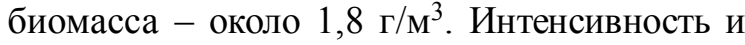
направленность круговорота органического вещества в водоеме зависит от деятельности сапрофитной микрофлоры, численность этой группы бактерий в экспериментальных заливах колебалась в пределах от 3,0 до 27,2 тыс. кл/мл. Среднее составило - 12,0 тыс. кл/мл, что в 6 раз превысило данные, полученные в контрольных участках водохранилища. Темп размножения водной микрофлоры в исследуемых заливах в летний период 2017 г. был достаточно высоким: удвоение бактериальной биомассы в единицу времени происходило со скоростью 8,8-20,5 час. В основном это было связано с интенсивным прогревом водных масс и наличием достаточного количества легкоусвояемых органических веществ. В экспериментальных заливах в биотопах темп 
Внедрение природосберегающих технологий - экологический императив в развитии регионов

Таблица 6

Показатели состояния воды в исследуемых заливах Волгоградского водохранилища, 2017 год

\begin{tabular}{|c|c|c|c|c|}
\hline \multirow{2}{*}{$\begin{array}{c}\text { Исследуемые } \\
\text { показатели }\end{array}$} & \multicolumn{2}{|c|}{ Левый берег } & \multicolumn{2}{|c|}{ Правый берег } \\
\hline & $\begin{array}{c}\text { Контрольный } \\
\text { залив }\end{array}$ & $\begin{array}{c}\text { Эксперименталь- } \\
\text { ный залив }\end{array}$ & $\begin{array}{c}\text { Контрольный } \\
\text { залив }\end{array}$ & $\begin{array}{c}\text { Эксперименталь- } \\
\text { ный залив }\end{array}$ \\
\hline \multirow[t]{2}{*}{$\mathrm{pH}$} & $7.3-8.1$ & $7.6-8.8$ & $7.3-8.1$ & $7.7-8.8$ \\
\hline & 7.69 & 8.08 & 7.78 & 7.78 \\
\hline \multirow{2}{*}{$\begin{array}{l}\text { Растворенный ки- } \\
\text { слород, } \mathrm{MrO}_{2} / \text { дм }^{3}\end{array}$} & $4.9-9.6$ & $8.25-10.3$ & $4.9-9.61$ & $7.7-8.8$ \\
\hline & 7.89 & 9.28 & 7.84 & 7.78 \\
\hline \multirow{2}{*}{ БПК } & $0.5-3.3$ & $0.9-2.2$ & $0.6-5.2$ & $0.5-2.2$ \\
\hline & 2.24 & 1.75 & 2.33 & 2.99 \\
\hline \multirow[t]{2}{*}{ ХПК, мгО/дм ${ }^{3}$} & $8.5-24.2$ & $12.0-25.7$ & $8.5-24.2$ & $12.0-25.7$ \\
\hline & 18.5 & 17.0 & 22.1 & 20.4 \\
\hline \multirow[t]{2}{*}{$\mathrm{NH}_{4}$ мг/дм ${ }^{3}$} & $0.2-1.37$ & $0.25-0.40$ & $0.20-1.06$ & $0.28-0.40$ \\
\hline & 0.75 & 0.30 & 0.57 & 0.46 \\
\hline \multirow{2}{*}{$\mathrm{NO}_{2}^{-}$мг/дм ${ }^{3}$} & $0.006-0.039$ & $0.006-0.021$ & $0.07-1.40$ & $0.006-0.021$ \\
\hline & 0.028 & 0.012 & 0.69 & 0.017 \\
\hline \multirow[t]{2}{*}{$\mathbf{\Sigma} \mathbf{N}$ мг/дм ${ }^{3}$} & $0.83-1.969$ & $0.435-0.439$ & $0.47-1.44$ & $0.42-1.07$ \\
\hline & 1.204 & 0.437 & 1.094 & 0.952 \\
\hline \multirow{2}{*}{$P-P O_{4}^{3-}$ мг/дм ${ }^{3}$} & $0.03-0.08$ & $0.03-0.06$ & $0.03-0.10$ & $0.03-0.10$ \\
\hline & 0.07 & 0.03 & 0.08 & 0.08 \\
\hline \multirow[t]{2}{*}{$\mathrm{Si} \mathrm{мг/дм}{ }^{3}$} & $2.2-2.9$ & $2.3-2.4$ & $2.2-2.9$ & $2.3-2.4$ \\
\hline & 2.35 & 2.47 & 2.5 & 2.78 \\
\hline \multirow[t]{2}{*}{$\mathrm{Fe}_{\text {щ. }} \mathrm{M \Gamma} / д \mathrm{M}^{3}$} & $H / o-0.19$ & $H / o-0.12$ & $H / o-0.87$ & $\mathrm{H} / \mathrm{o}-0.12$ \\
\hline & 0.13 & 0.12 & 0.12 & 0.12 \\
\hline \multirow[t]{2}{*}{ 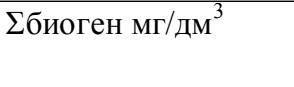 } & $\underline{3.583-5.089}$ & $2.919-2.935$ & $3.51-4.37$ & $3.32-4.56$ \\
\hline & 3.881 & 2.927 & 3.790 & 3.828 \\
\hline
\end{tabular}

Примечание. Составлено авторами.

размножения и продуцирования бактериальной биомассы был более низким: константа скорости роста в эксперименте составила 1,26 (в контрольном заливе - в 1,8 раза, в среднем по водохранилищу - в 1,6 раза). В экспериментальных заливах величина кислорода, используемого биопланктоном на дыхание, колебалась в пределах: 0,3-1,2 мг $\mathrm{O}_{2} /$ л, что было в 1,5 раза ниже, чем в контрольных. Снижение функциональной активности биопланктона в экспериментальных заливах свидетельствует о низких скоростях трансформации органического вещества в данных биотопах, что объясняется токсическим ингибированием функционирования микробных сообществ цианобактериями. В 2017 г. в нижней зоне Волгоградского водохранилища был зарегистрирован 221 таксон водорослей, из них диатомовых - 97, зеленых - 54, синезеленых - 37, пирофитовых - 20, эвгленовых - 13, золотистых - 2, желтозеленых - 1 . Сезонные количественные показатели водорослей колебались в широких пределах от 0,084 до 69,86 мнл кл/л; общая биомасса от 0,016 до 5,9 г/м ${ }^{3}$. Основу биомассы составляли 4 отдела водорослей: диатомовые, синезеленые, зеленые и пирофитовые. Доминирующими формами среди диатомовых были виды родов Stephanodiscus hantzschii, Cyclotella; среди синезеленых основными видами были Microcystis aeruginosa и Phormidium foveolarum; из зеленых водорослей встречались виды Chlamydomonas, peже-Pandorina morum; из пирофитовых массовым был вид Chroomonas acuta [Гелашвили и др., 2015].

Chlorella vulgaris была зарегистрирована с июня по август в экспериментальных заливах с показателями от 0,1 до $10 \%$ общей биомассы фитопланктона. Максимальная численность и биомасса синезеленых водорослей при низких количественных показателях зеленых водорослей была отмечена в контрольных заливах: Яблоневый и Красные отмели. Здесь наблюдалось образование пленки из разлагающихся синезеленых водорослей. 
Анализ количественных показателей фитопланктона в исследуемых участках водохранилища выявил изменение структуры альгоценозов экспериментальных заливов под воздействием штамма Chlorella vulgaris в сторону увеличения зеленых водорослей и снижения синезеленых. По видовому составу зоопланктона за период исследований (2017 г.) в нижней зоне Волгоградского водохранилища зарегистрировано 66 видов голопланктона, из них Rotatoria - 16, Copepoda - 22, Cladocera - 28. Увеличение численности зоопланктона в августе 2017 г. произошло за счет массового выброса велигеров дрейссены. В целом развитие зоопланктоценозов русловой зоны находилось на уровне среднемноголетних показателей.

Интегральную оценку влияния штамма Chlorella vulgaris ИФР № C-111 на параметры экосистемы экспериментальных заливов производили методом определения функции «желательности». В качестве индикаторных показателей, характеризующих состояние контрольных и экспериментальных участков экосистемы использовали: концентрацию растворенного кислорода в воде, прозрачность воды, биомассу зеленых водорослей, биомассу зоопланктона, биомассу синезеленых водорослей. С учетом задач альголизации водохранилища «желательным» являлось увеличение первых четырех показателей, «нежелательным» показатель биомассы синезеленых водорослей. Перевод различных индикаторных параметров экосистемы в единую цифровую шкалу функции «желательности» производился по формуле 1. На начальном этапе были рассчитаны значения функции «желательности» для каждого из исследуемых заливов за каждый месяц наблюдения. Далее полученные на первом этапе значения обобщенных функций «желательности» для каждого залива были интегрированы в две группы: по эксперименту и контролю. Результаты оценки представлены на рисунке 4. Заливы, на которых производился эксперимент по вселению штамма Chlorella vulgaris ИФР № С-111, на протяжении всего вегетационного сезона имели более высокие показатели функции «желательности» для экосистем по сравнению с контрольными.

На основании полученных результатов можно сделать следующие выводы: альголизация экспериментальных заливов Волгоградского водохранилища штаммом Chlorella vulgaris ИФР № C-111 привела к улучшению основных эколого-водохозяйственных параметров экосистемы. Расчет функции «желательности» на основе полученных данных позволил рассчитать зависимость между описываемыми явлениями:

$$
D=0,169+0,0557 \ln (P)
$$

где $D$ - значение функции «желательности» в конце вегетационного сезона (сентябрь 2017 г.); $P$ - суммарная за сезон плотность альголизации, литры суспензии на 1 га.

Коэффициент детерминации указанной зависимости довольно высок и составляет 0,71. Увеличение плотности вселения штам-

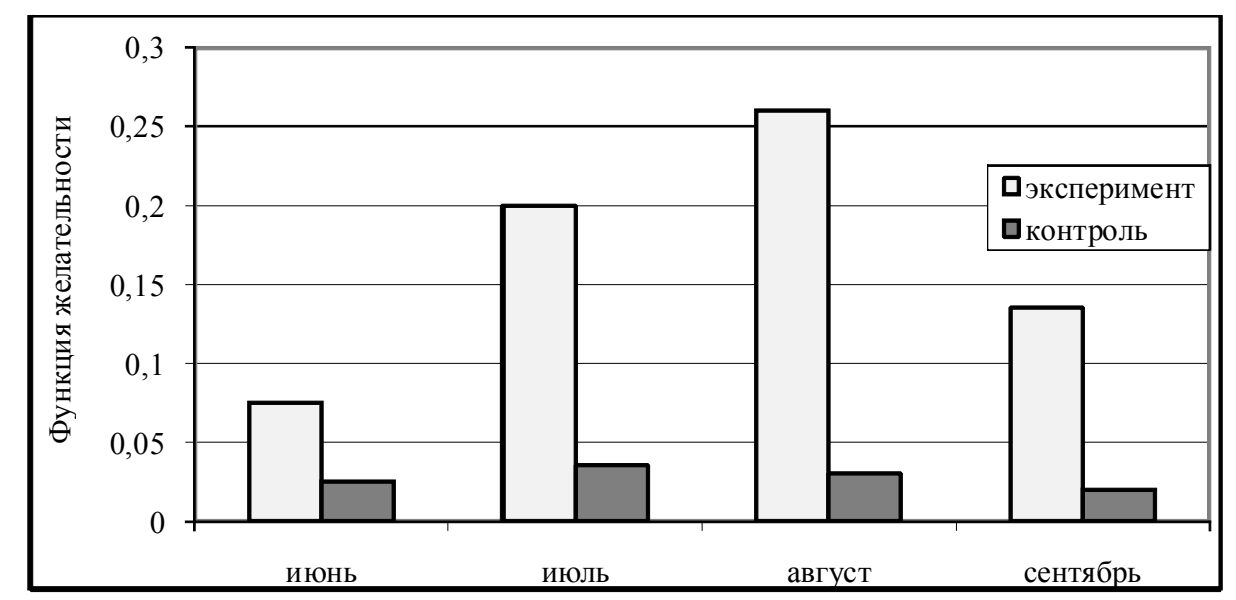

Рис. 4. Значение обобщенной функции «желательности» для исследуемых заливов Волгоградского водохранилища, 2017 год 
ма Chlorella vulgaris ИФР № С-111 влечет за собой увеличение индекса «желательности» и формирование более востребованных параметров экосистемы. Полученная при исследовании расчетная модель функции «желательности» чрезвычайно важна в практическом плане, поскольку позволяет оптимизировать материальные затраты на проведение альголизации водоемов [Гелашвили и др., 2015; Перспективы развития рыболовства..., 2017]. Расчеты ученых ФГБНУ ВНИИОЗ (г. Волгоград) показывают, что диапазон затрат, при котором оптимальным будет считаться альголизация водоема, составляет 10000 руб. на 1 га.

\section{Выводы}

Загрязнение водных ресурсов является одной из важнейших проблем XXI века. Несмотря на принимающиеся за последние годы меры по улучшению экологического состояния водоемов, проблема «цветения» воды остается весьма актуальной. Комплексный системный анализ оценки состояния исследуемого Волгоградского водохранилища с различной природно-техногенной нагрузкой по заливам позволил выявить причины, определить факторы природного и техногенного эвтрофирования водоема. При проведении мониторинга экспериментальных и контрольных заливов Волгоградского водохранилища были обстоятельно изучены гидрохимические и гидробиологические показатели воды, состояние бентоса. Установлено, что присутствие штамма Chlorella vulgaris ИФР №С-111 в экспериментальных заливах снижает деятельность синезеленых водорослей, создает благоприятные условия для формирования кормовой базы. Водоросли, являясь неотъемлемой частью природных экосистем, представляют собой источник разнообразных ценных и уникальных биоорганических соединений, они богаты белками, витаминами, микроэлементами и биологически активными веществами. Выделяя в окружающую среду различные биологически активные вещества, они способны оказывать регуляторное воздействие на другие организмы биоценоза. Перспективный и экологически безопасный метод предотвращения «цветения» воды с помощью вселения штам- ма Chlorella vulgaris ИФР №C-111 в водные объекты достаточно непрост, поскольку мы имеем дело с живой природной средой, находящейся в постоянном движении и преобразовании под воздействием многочисленных внешних и внутренних факторов. Требуют дальнейшего исследования и вопросы разработки инвестиционных проектов по созданию на Юге России производств культивирования микроводорослей.

\section{СПИСОК ЛИТЕРАТУРЫ}

Водная стратегия Российской Федерации на период до 2025 года : Распоряжение Правительства Российской Федерации от 27 августа 2009 года №1235-p. - Электрон. текстовые дан. - Режим доступа: https://www.garant.ru/ products/ipo/prime/doc/2069399/ (дата обращения: 15.08.2019). - Загл. с экрана.

Гелашвили, Д. Б. Фракталы и мультифракталы в биоэкологии : монография / Д. Б. Гелашвили, Д. И. Иудин, Г. С. Розенберг // Международный журнал экспериментального образования. -2015 . - № 8 (2). - С. 186.

Иншаков, О. В. Стратегические идеи из регионовпотенциал эффективной консолидации (размышления главного редактора) / О. В. Иншаков // Региональная экономика. Юг России. 2017. - № 1 (15). - C. 4-12.

Медведев, А. В. Методологический подход в обосновании рационального использования водных ресурсов в сельском хозяйстве / А. В. Медведев, Л. Н. Медведева, П. Д. Ванеева // Пути повышения эффективности орошаемого земледелия. -2019. - № 2 (74). - С. 115-124.

Медведева, Л. Н. Стратегия развития сельских территорий через систему координат: качество жизни населения /Л. Н. Медведева, М. А. Тимошенко // Экономика и предпринимательство. - 2017. - № 10. - С. 297-303.

Мелихов, В. В. Стратегия управления водными ресурсами на уровне водосборных бассейнов / В. В. Мелихов // Современные тенденции развития аграрного комплекса : материалы V Междунар. науч.-практ. конф. молодых ученых, посвящ. 25-летию Прикаспийского науч.исслед. ин-та аридного земледелия. - Соленое Займище : Прикаспийский НИИ аридного земледелия, 2016. - С. 130-132.

Мониторинг экологического состояния водохранилищ ВДСК при вселении штамма хлореллы ИФР № С-111 / Л. А. Птицына [и др.] // Крымская инициатива - Экологическая безопас- 
ность регионов: концептуально-теоретические, практические, природоохранные и мировоззренческие аспекты : сб. материалов I Bсерос. междисциплинар. науч.-практ. конф. Симферополь : [б. и.], 2017. - С. 197-201.

О Стратегии экологической безопасности Российской Федерации на период до 2025 года. Указ Президента Российской Федерации от 19.04.2017 № 176. - Электрон. текстовые дан. Режим доступа: http://pravo.gov.ru/proxy/ips/ ?docbody $=$ \&nd $=102430636 \& \mathrm{rdk}=\&$ firstDoc $=$ 1\&lastDoc=1 (дата обращения: 15.07.2019). Загл. с экрана.

Перспективы развития рыболовства в водоемах южных регионов Российской Федерации / М. В. Московец [и др.] // Актуальные направления научных исследований в АПК: от теории к практике : материалы Нац. науч.-практ. конф. (г. Волгоград, 10 ноября 2017 г.). - Волгоград : Волгоградский ГАУ, 2017. - С. 205-208.

Проблема развития аквакультуры в Волго-Каспийском районе / В. В. Мелихов [и др.] // Формирование и развитие сельскохозяйственной науки в XXI веке : сб. науч. ст. ПНИИАЗ. - Соленое Займище : Прикаспийский НИИ аридного земледелия, 2016. - С. 230-235.

Проблемы экологического состояния водных ресурсов волжского бассейна и пути их решения / М. В. Московец [и др.] // Современные технологии и достижения науки в АПК : сб. науч. тр. Всерос. науч.-практ. конф. - Махачкала : Дагестанский ГАУ им. М.А. Джамбулатова, 2018. - С. 50-55.

Фролова, М. В. Современная биотехнология в улучшении качества воды открытых водоемов многоцелевого назначения / М. В. Фролова, О. П. Комарова, М. В. Московец // Известия Нижневолжского агроуниверситетского комплекса: Наука и высшее профессиональное образование. -2018. - № 4 (52). - С. 213-218.

Шилькрот, Г. С. Причины антропогенного эвтрофирования водоемов / Г. С. Шилькрот // Итоги науки и техники. Общая Экология. Биоценология. Гидробиология. Т. 2. Антропогенное эвтрофирование водоемов. - М. : ВИНИТИ, 1975. - C. 61-96.

Final Draft of Climate Deal Formally Accepted in Paris. CNN. Cable News Network, Turner Broadcasting System, Inc. (2015). - Electronic text data. - Mode of access: https:/edition.cnn.com/2015/12/12/ world/global-climate-change-conference-vote/ (accessed 12 December 2018). - Title from screen.

Green Technologies: The Basis for Integration and Clustering of Subjects at the Regional Level of Economy/V. V. Melikhov [et al.] // Integration and Clustering for Sustainable Economic Growth. - [S. 1.] : Springer 2017. - P. 365-382.

United Nations Official Document. - Electronic text data. - Mode of access: https:/www.un.org/ga/ search/view_doc.asp?symbol=A/RES/70/ 1\&Lang=E (accessed 23 August 2018). - Title from screen.

\section{REFERENCES}

Vodnaya strategiya Rossiyskoy Federatsii na period do 2025 goda. Rasporyazhenie Pravitelstva Rossiyskoy Federatsii ot 27 avgusta 2009 goda №1235-p [Water Strategy of the Russian Federation for the Period Until 2025. Order of the Government of the Russian Federation of August 27, 2009 no. 1235-p]. URL: https://www. garant.ru/products/ipo/prime/doc/2069399/ (accessed 15 August 2019).

Gelashvili D.B., Iudin D.I., Rozenberg G.S. Faktaly i multifaktaly v bioekologii: monografiya [Factory and Multifactory in Bioecology. Monograph]. Mezhdunarodnyy zhurnal eksperimentalnogo obrazovaniya [International Journal of Experimental Education], 2015, no. 8(2). 186 p.

Inshakov O.V. Strategicheskie idei iz regionov-potentsial effektivnoy konsolidatsii (razmyshleniya glavnogo redaktora) [Strategic Ideas from the Regions - The Potential for Effective Consolidation (Reflections of the Editor-in-Chief)]. Regionalnaya ekonomika. Yug Rossii [Regional Economy. South of Russia], 2017, no. 1 (15), pp. 4-12.

Medvedev A.V., Medvedeva L.N., Vaneeva P.D. Metodologicheskiy podkhod v obosnovanii ratsionalnogo ispolzovaniya vodnykh resursov v selskom khozyaystve [Methodological Approach in Substantiation of Rational Use of Water Resources in Agriculture]. Puti povysheniya effektivnosti oroshaemogo zemledeliya, 2019, no. 2 (74), pp. 115-124.

Medvedeva L.N., Timoshenko M.A. Strategiya razvitiya selskikh territoriy cherez sistemu koordinat: kachestvo zhizni naseleniya [Strategy of Development of Rural Areas Through the Coordinate System: The Quality of Life of the Population]. Ekonomika i predprinimatelstvo [Journal of Economy and Entrepreneurship], 2017, no. 10, pp. 297-303.

Melikhov V.V. Strategiya upravleniya vodnymi resursami na urovne vodosbornykh basseynov [Strategy of Water Resources Management at the Level of Catchment Basins]. Sovremennye tendentsii razvitiya agrarnogo kompleksa. Materialy $V$ mezhdunar. nauch.-prakt. konf. molodykh uchenykh, posvyashch. 25-letiyu Prikaspiyskogo nauch.-issl. instituta aridnogo 
zemledeliya [Current Trends in the Development of the Agricultural Sector. Proceedings of the $5^{\text {th }}$ International Scientific and Practical Conference of Young Scientists Dedicated to the $25^{\text {th }}$ Anniversary of Caspian Research Institute of Arid Agriculture]. Solenoe Zaymishche, Prikaspiyskiy NII aridnogo zemledeliya, 2016, pp. 130-132.

Ptitsyna L.A., Frolova M.V., Komarova O.P., Moskovects M.V., Toropov A.Yu. Monitoring ekologicheskogo sostoyaniya vodokhranilishch VDSK pri vselenii shtamma khlorelly IFR№ S-111 [Monitoring of Ecological State of Reservoirs of the Volga-to-Don Channel at the Introduction of Chlorella IGF no. C-111 Strain]. Krymskaya initsiativa - Ekologicheskaya bezopasnost regionov: kontseptualno-teoreticheskie, prakticheskie, prirodookhrannye $i$ mirovozzrencheskie aspekty: sb. materialov I Vseros. mezhdistsiplinar. nauch.-prakt. konf. [Crimean Initiative - Environmental Security of Regions: Conceptual, Theoretical, Practical, Environmental and Worldview Aspects. Proceedings of the $1^{\text {st }}$ All-Russian Interdisciplinary Scientific and Praktical Conference]. Simferopol, 2017, pp. 197-201.

O Strategii ekologicheskoy bezopasnosti Rossiyskoy Federatsii na period do 2025 goda. Ukaz Prezidenta Rossiyskoy Federatsii ot 19.04.2017 № 176 [On the Strategy of Environmental Safety of the Russian Federation for the Period Until 2025. Decree of the President of the Russian Federation of April 19, 2017 no. 176]. URL: http:// pravo.gov.ru/proxy/ips/?docbody $=\& n d=$ $102430636 \& \mathrm{rdk}=\&$ firstDoc $=1 \&$ lastDoc $=1$ (accessed 15 July 2019).

Moskovets M.V., Frolova M.V., Ptitsyna L.A., Toropov A.Yu. Perspektivy razvitiya rybolovstva $v$ vodoemakh yuzhnykh regionov Rossiyskoy Federatsii [Prospects of Development of Fishery in Reservoirs of the Southern Regions of the Russian Federation]. Aktualnye napravleniya nauchnykh issledovaniy $v$ APK: ot teorii $k$ praktike. Materialy Nats. nauch.-prakt. konf. (g. Volgograd, 10 noyabrya 2017 g.) [Current Directions of Research in Agriculture: From Theory to Practice. Proceedings of the National Scientific and Praktical Conference (Volgograd, November 10, 2017)]. Volgograd, Volgogradskiy GAU, 2017, pp. 205-208.

Melikhov V.V., Bolotin A.G., Frolova M.V., Moskovets M.V., Ptitsyna L.A., Toropov A.Yu. Problema razvitiya akvakultury v Volgo-Kaspiyskom rayone [Problem of Aquaculture Development in the Volga-Caspian Region]. Formirovanie i razvitie selskokhozyaystvennoy nauki $v$ XXI veke.
Sbornik nauchnykh statey FGBNU «PNIIAZ» [Formation and Development of Agricultural Science in the $21^{\text {st }}$ Century. Collection of Scientific Articles of the Federal State Budgetary Scientific Institution Caspian Research Institute of Arid Agriculture]. Solenoe Zaymishche, Prikaspiyskiy NII aridnogo zemledeliya, 2016, pp. 230-235.

Moskovets M.V., Frolova M.V., Ptitsyna L.A., Toropov A.Yu. Problemy ekologicheskogo sostoyaniya vodnykh resursov volzhskogo basseyna i puti ikh resheniya [Problems of Ecological Condition of Water Resources of the Volga Basin and Ways of Their Solving]. Sovremennye tekhnologii i dostizheniya nauki v APK: sb. nauch. tr. Vseros. nauch.-prakt. konf. [Modern Technologies and Achievements of Science in Agriculture. Proceedings of the All-Russian Scientific and Practical Conference]. Makhachkala, DagestanskiyGAUim. M.A. Dzhambulatova, 2018, pp. 50-55.

Frolova M.V., Komarova O.P., Moskovets M.V. Sovremennaya biotekhnologiya $\mathrm{v}$ uluchshenii kachestva vody otkrytykh vodoemov mnogotselevogo naznacheniya [Modern Biotechnology in Improving the Quality of Water of Open Reservoirs, Multi-Purpose]. Izvestiya Nizhnevolzhskogo agrouniversitetskogo kompleksa: Nauka i vysshee professionalnoe obrazovanie [Proceedings of Nizhnevolzskiy Agrouniversity Complex: Science and Higher Vocational Education], 2018, no. 4(52), pp. 213-218.

Shilkrot G.S. Prichiny antropogennogo evtrofirovaniya vodoemov [Causes of Anthropogenic Eutrophication of Water Bodies]. Itogi nauki $i$ tekhniki. Obshchaya Ekologiya. Biotsenologiya. Gidrobiologiya. T. 2. Antropogennoe evtrofirovanie vodoemov [Results of Science and Technology. General Ecology. Biocenology. Hydrobiology. Vol. 2. Anthropogenic Eutrophication of Reservoirs]. Moscow, VINITI Publ., 1975, pp. 61-96.

Final Draft of Climate Deal Formally Accepted in Paris. CNN. Cable News Network, Turner Broadcasting System, Inc. (2015). URL: https:// edition.cnn.com/2015/12/12/world/globalclimate-change-conference-vote/ (accessed 12 December 2018).

Melikhov V.V., Medvedeva L.N., Novikov A.A., Komarova O.P. Green Technologies: The Basis for Integration and Clustering of Subjects at the Regional Level of Economy. Integration and Slustering for Sustainable Economic Growth, 2017, pp. 365-382.

United Nations Official Document. URL: https://www. un.org/ga/search/view_doc.asp?symbol=A/ RES/70/1\&Lang=E (accessed 23 August 2018). 


\section{Information About the Authors}

Ljudmila N. Medvedeva, Doctor of Sciences (Economics), Leading Researcher, Head of the Laboratory of Economic Research, All-Russian Research Institute of Irrigated Agriculture, Timiryazeva St., 9, 400002 Volgograd, Russian Federation; Professor, Volzhsky Polytechnical Institute, Branch of Volgograd State Technical University, Engelsa St., 42a, 404121 Volzhsky, Russian Federation, milena.medvedeva2012@yandex.ru, https://orcid.org/0000-0002-3650-2083

Maria V. Frolova, Candidate of Sciences (Biology), Senior Researcher, Head of the Laboratory of Irrigation Reclamation, All-Russian Research Institute of Irrigated Agriculture, Timiryazeva St., 9, 400002 Volgograd, Russian Federation, mikkinfm@gmail.com, https://orcid.org/0000-0003-0778-228X

Maria V. Moskovets, Senior Researcher, All-Russian Research Institute of Irrigated Agriculture, Timiryazeva St., 9, 400002 Volgograd, Russian Federation, vniioz-algo@yandex.ru, https://orcid.org/0000-0003-1997-6313

Artem V. Medvedev, Researcher, Laboratory of Economic Research, All-Russian Research Institute of Irrigated Agriculture, Timiryazeva St., 9, 400002 Volgograd, Russian Federation, artemmedwedew@rambler.ru,https://orcid.org/0000-0002-2690-314X

\section{Информация об авторах}

Людмила Николаевна Медведева, доктор экономических наук, ведущий научный сотрудник, заведующая лабораторией экономических исследований, Всероссийский научно-исследовательский институт орошаемого земледелия, ул. Тимирязева, 9, 400002 г. Волгоград, Российская Федерация; профессор, Волжский политехнический институт (филиал) ВолгГТУ, ул. Энгельса, 42a, 404121 г. Волжский, Российская Федерация, milena.medvedeva2012@yandex.ru, https://orcid.org/0000-0002-3650-2083

Мария Викторовна Фролова, кандидат биологических наук, старший научный сотрудник, заведующая лабораторией оросительных мелиораций, Всероссийский научно-исследовательский институт орошаемого земледелия, ул. Тимирязева, 9, 400002 г. Волгоград, Российская Федерация, mikkinfm@gmail.com, https://orcid.org/0000-0003-0778-228X

Мария Васильевна Московец, старший научный сотрудник, Всероссийский научно-исследовательский институт орошаемого земледелия, ул. Тимирязева, 9, 400002 г. Волгоград, Российская Федерация, vniioz-algo@yandex.ru, https://orcid.org/0000-0003-1997-6313

Артем Владимирович Медведев, научный сотрудник лаборатории экономических исследований, Всероссийский научно-исследовательский институт орошаемого земледелия, ул. Тимирязева, 9, 400002 г. Волгоград, Российская Федерация, artemmedwedew@rambler.ru, https://orcid.org/0000-0002-2690-314X 